Hutagalung, A.M.: Pengaruh Model Pembelajaran

Peningkatan Kemampuan Berpikir Terhadap

Hasil Belajar Pada Materi Pokok Besaran dan

Pengukuran di Kelas X SMA Negeri 1 Balige.

\title{
PENGARUH MODEL PEMBELAJARAN PENINGKATAN \\ KEMAMPUAN BERPIKIR TERHADAP HASIL BELAJAR \\ PADA MATERI POKOK BESARAN DAN PENGUKURAN DI KELAS X SMA NEGERI 1 BALIGE
}

\author{
Andar M. Hutagalung \\ Jurusan Pendidikan Fisika \\ Program Pascasarjana Universitas Negeri Medan
}

\begin{abstract}
Abstrak. Tujuan penelitian ini adalah meningkatkan hasil belajar Fisika siswa yang diterapkan model pembelajaran peningkatan kemampuan berpikir pada materi pokok Besaran dan Pengukuran. Penelitian ini merupakan jenis penelitian quasi eksperimen, populasi dalam penelitian ini adalah seluruh siswa kelas X SMA Negeri 1 Balige semester I tahun ajaran 2008/2009 yang berjumlah 6 kelas. Sampel penelitian ini diambil dari dua kelas yang homogen dari semua kelas populasi yaitu kelas $\mathrm{X}_{\mathrm{E}}$ (sebagai kelas eksperimen) dan kelas $\mathrm{X}_{\mathrm{F}}$ (Sebagai kelas kontrol) yang masing-masing berjumlah 40 orang. Dari hasil uji $t$ diperoleh untuk postes $t_{\text {hitung }}=5,303$ sedangkan $t_{\text {tabel }}=1,994$ karena $t_{\text {hitung }}>\mathrm{t}_{\text {tabel }}(5,303>1,994)$ maka dapat disimpulkan bahwa ada pengaruh model pembelajaran peningkatan kemampuan berpikir terhadap hasil belajar Fisika siswa pada materi pokok Besaran dan Pengukuran di SMA Negeri 1 Balige.
\end{abstract}

Kata kunci: model pembelajaran, peningkatan kemampuan berpikir, hasil belajar

\section{Pendahuluan}

Upaya peningkatan kualitas pendidikan merupakan salah satu fokus dalam pembangunan pendidikan di Indonesia dewasa ini. Salah satu masalah pendidikan yang perlu mendapatkan perhatian langsung adalah peningkatan sumber daya manusia Indonesia. Secara operasional guru adalah garda terdepan yang dapat langsung melakukan tindakan-tindakan perbaikan mutu pendidikan tersebut melalui peningkatan kualitas hasil belajar siswa. Menurut Atmadi (2000) masalah utama yang kita hadapi adalah kenyataan bahwa pada umumnya mutu pendidikan kita relative masih rendah.

Fisika sebagai salah satu pure science merupakan ilmu yang sangat menunjang untuk dapat mengikuti dan mengimbangi perkembangan Ilmu Pengetahuan dan Teknologi yang sangat global saat ini. Di sekolah, pelajaran Fisika diajarkan dengan tujuan untuk memper- siapkan siswa agar dapat menerapkan konsepkonsep Fisika dalam kahidupan sehari-hari dengan melatih melakukan pengamatan, percobaan, diskusi dan mengambil kesimpulan dari kegiatan-kegiatan tersebut. Dengan demikian, siswa dapat menemukan, membuktikan, merealisasikan dan mengaplikasikan suatu konsep dalam kehidupan sehari-hari. Nilai hasil belajar siswa dapat lebih ditingkatkan apabila pembelajaran berlangsung secara efisien dengan ditunjang oleh tersedianya sarana dan prasarana pendukung serta kecakapan guru dalam pengelolaan kelas dan penguasaan materi yang cukup memadai.

Hasil belajar siswa yang rendah untuk pelajaran Fisika dapat disebabkan oleh beberapa hal antara lain: (1) Rendahnya minat siswa dalam belajar Fisika; (2) Kurangnya pemahaman siswa dalam penguasaan materi pelajaran; (3) Kesalahan konsepsi siswa dalam setiap pokok 
Hutagalung, A.M.: Pengaruh Model Pembelajaran Peningkatan Kemampuan Berpikir Terhadap Hasil Belajar Pada Materi Pokok Besaran dan Pengukuran di Kelas X SMA Negeri 1 Balige.

bahasan; (4) Penggunaan metode pengajaran yang kurang tepat; (5) Perbedaan intelegensi siswa.

Dalam kegiatan belajar mengajar suatu disiplin ilmu khususnya Fisika, guru harus memiliki strategi mengajar yang dapat membuat siswa belajar secara aktif, efisien dan efektif serta tercapainya tujuan pembelajaran umum atau khusus yang diharapkan. Guru harus menanamkan tiga unsur dalam pembelajaran Fisika, yaitu pengetahuan, keterampilan proses (kreativitas), dan sikap. Selain itu, guru harus menguasai dan menerapkan teknik penyajian pelajaran.

Dari pernyataan diatas secara garis besar kunci permasalahan terketak pada guru mata pelajaran. Salah satu metode yang sering diterapkan guru dalam pembelajaran adalah metode ceramah, dan siswa belajar hanya terfokus pada materi yang disampaikan guru. Akibatnya dibutuhkan waktu yang banyak untuk menyampaikan seluruh materi, sehingga menyebabkan kegiatan pembelajaran kurang efisien dan banyak waktu yang terbuang hanya untuk mendengarkan penjelasan guru. Hal ini menyebabkan siswa meras abosan dan jenuh untuk belajar Fisika yang berakibat hasil belajarnya rendah. Jadi, untuk mengatasi hal ini diperlukan sistem pengajaran yang dapat merangsang minat belajar siswa, salah satunya adalah dengan menerapkan model pembelajaran peningkatan kemampuan berfikir.

Model pembelajaran peningkatan kemampuan berfikir merupakan model pembelajaran yang bertumpu pada proses perbaikan dan peningkatan kemampuan berfikir siswa (Sanjaya, 2006). Model pembelajaran kemampuan berfikir bukan hanya sekedar model pembelajaran yang diarahkan agar peserta didik dapat mengingat dan memahami berbagai data, fakta atau konsep akan tetapi bagaimana data, fakta dan konsep tersebut dijadikan sebagai alat untuk melatih kemampuan berfikir siswa dalam memahami dan memecahkan suatu persoalan.

Ada tiga karakteristik utama model pembelajaran peningkatan berfikir yaitu (Sanjaya, 2006):
Jurnal Pendidikan Fisika

p-ISSN 2252-732X

e-ISSN 2301-7651

1. Proses pembelajaran melalui model pembelajaran peningkatan kemampuan berfikir menekankan kepada proses mental siswa secara maksimal

2. Model pembelajaran peningkatan kemampuan berfikir dibangun dalam nuansa dialogis dan proses tanya jawab secara terus menerus.

3. Model pembelajaran peningkatan kemampuan berfikir adalah model pembelajaran yang menyadarkan kepada dua sisi yang sama pentingnya, yaitu sisi proses dan hasil belajar.

Model pembelajaran peningkatan kemampuan berfikir menekankan kepada keterlibatan siswa secara penuh dalam belajar. Hal ini sesuai dengan hakikat model pembelajaran peningkatan kemampuan berfikir yang tidak mengharapkan siswa sebagai objek belajar yang hanya duduk mendengar penjelasan guru kemudian mencatat untuk dihafalkan. Cara yang demikian bukan saja tidak sesuai dengan hakikat belajar sebagai usaha memperoleh pengalaman, akan tetapi juga dapat menghilangkan gairah dan motivasi belajar siswa (Sanjaya, 2006).

Berdasarkan latar belakang diatas, dapat diidentifikasi masalah yang muncul, yaitu: (1) Hasil belajar Fisika siswa masih rendah; (2) Kurangnya minat dan motifasi untuk mempelajari Fisika; (3) Metode penyampaian materi yang diterapkan guru kurang menarik minat siswa sehingga perlu diterapkan model pembelajaran. Masalahnya dibatasi pada: (1) Subyek penelitian ini adalah siswa kelas $\mathrm{X}$ semester I SMA Negeri 1 Balige tahun ajaran 2008/2009 yang dibatasi hanya dua kelas yaitu kelas eksperimen dan kelas kontrol; (2) Model pembelajaran yang diterapkan dibatasi pada model pembelajaran peningkatan kemampuan berfikir diterapkan dikelas eksperimen; (3) Model pembelajaran yang diterapkan dibatasi pada model pembelajaran konvensional diterapkan pada kelas Kontrol; (4) Hasil belajar siswa dibatasi pada hasil belajar Fisika pada materi pokok Besaran dan Pengukuran.

Adapun rumusan masalah dalam penelitian ini adalah bagaimana pengaruh model pembelajaran peningkatan kemampuan berfikir 
Hutagalung, A.M.: Pengaruh Model Pembelajaran Peningkatan Kemampuan Berpikir Terhadap Hasil Belajar Pada Materi Pokok Besaran dan Pengukuran di Kelas X SMA Negeri 1 Balige.

terhadap hasil belajar Fisika pada materi pokok Besaran dan Pengukuran? Sesuai dengan rumusan masalah maka tujuan yang akan dicapai dalam penelitian ini adalah untuk meningkatkan hasil belajar Fisika siswa yang diterapkan model pembelajaran peningkatan kemampuan berfikir pada materi pokok Besaran dan Pengukuran.

\section{Hakekat Belajar}

Ada tiga komponen penting belajar yakni kondisi eksternal yaitu stimulus dari lingkungan dalam acara belajar, kondisi internal yang menggambarkan keadaan internal dan proses kognitif siswa, dan hasil balajar yang menggambarkan informasi verbal, keterampilan intelek, keterampilan motorik, sikap, dan siasat kognitif. Menurut Gagne ada tiga tahap dalam belajar yaitu:

1. Persiapan untuk belajar dengan melakukan tindakam mengarahkan perhatian, pengharapan, dan mendapatkan kembali informsi

2. Pemerolehan dan unjuk perbuatan digunakan untuk persepsi selektif, sandi semantik, pembangkitan kembali, respon dan penguatan

3. Alih belajar, yaitu pengisyaratan untuk membangkitkan dan memberlakukan secara umum (Dimyanti dan Mudjiono, 1999).

Setiap perilaku belajar selalu ditandai oleh ciri-ciri perubahan yang spesifik antara lain seperti dikemukakan berikut ini:

a. Belajar menyebabkan perubahan pada aspekaspek kepribadian yang berfungsi terus menerus, yang berpengaruh pada proses belajar selanjutnya.

b. Belajar hanya terjadi melalui pengalaman yang bersifat individual.

c. Belajar merupakan kegiatan yang bertujuan, yaitu arah yang ingin dicapai melalui proses belajar.

d. Belajar menghasilkan perubahan yang menyeluruh, melibakan keseluruhan tingkah laku secara integral.

e. Belajar adalah proses interaksi.

f. Belajar berlangsung dari yang paling sederhana sampai pada kompleks.
Jurnal Pendidikan Fisika

p-ISSN 2252-732X

e-ISSN 2301-7651

Belajar menghasilkan perilaku yang secara relatif tetap dalam dalam berpikir, merasa dan melakukan pada diri peserta didik. Perubahan tersebut terjadi sebagai hasil latihan, pengalaman, dan pengembangan yang hasilnya tidak dapat diamati secara langsung.

\section{Model pembelajaran}

Model dirancang untuk mewakili realitas yang sesungguhnya, walaupun model itu sendiri bukanlah realitas dari dunia yang sebenarnya. Atas dasar pengertian tersebut, maka model mengajar dapat dipahami sebagai kerangka konseptual yang mendeskripsikan dan melukiskan prosedur yang sistematik dalam mengorganisasikan pengalaman belajar dan pembelajaran untuk mencapai tujuan belajar tertentu, dan berfungsi sebagai pedoman bagi perencanaan pengajaran bagi para guru dalam melaksanakan aktivitas pembelajaran (Sagala, 2005).

\section{Model Pembelajaran Peningkatan Kemampuan Berpikir}

Model Pembelajaran Peningkatan Kemampuan Berpikir adalah model pembelajaran yang bertumpu kepada pengembangan kemampuan berpikir siswa melalui telaahan fakta-fakta atau pengalaman anak sebagai bahan memecahkan masalah yang diajukan (Sanjaya, 2006). Berpikir (thinking) adalah proses mental seseorang yang lebih dari sekedar mengingat (remembering) dan memahami (comprehending). Kemampuan berpikir memerlukan kemampuan mengingat dan memahami, oleh sebab itu kemampuan mengingat adalah kemapuan terpenting dalam mengembangkan kemampuan berpikir.

Ada tiga karakteristik utama model pembelajaran peningkatan kemampuan berpikir yaitu:

1. Proses pembelajaran melalui model pembelajaran peningkatan kemampuan berpikir menekankan kepada proses mental siswa secara maksimal.

2. Model Pembelajaran Peningkatan Kemampuan Berpikir dibangun dalam nuansa dialogis dan proses tanya jawab secara terus menerus. 
Hutagalung, A.M.: Pengaruh Model Pembelajaran Peningkatan Kemampuan Berpikir Terhadap Hasil Belajar Pada Materi Pokok Besaran dan Pengukuran di Kelas X SMA Negeri 1 Balige.

3. Model Pembelajaran Peningkatan Kemampuan Berpikir adalah model pembelajaran yang menyandarkan kepada dua sisi yang sama pentingnya, yaitu sisi proses dan hasil belajar.

Langkah-langkah dalam model pembelajaran peningkatan kemampuan berpikir ada enam yaitu (Sanjaya, 2006):

1. Tahap orientasi. Tahap orientasi dilakukan dengan penjelasan tujuan yang harus dicapai baik tujuan yang berhubungan dengan penguasaan materi pelajaran yang harus dicapai, maupun tujuan yang berhubungan dengan proses pembelajaran yang harus dimiliki siswa dan penjelasan proses pembelajaran yang harus dilakukan siswa, yaitu penjelasan tentang apa yang harus dilakukan siswa dalam setiap tahapan proses pembelajaran.

2. Tahap pelacakan. Tahap pelacakan adalah tahap penjajakan untuk memahami pengalaman dan kemampuan dasar siswa sesuai dengan tema yang akan dibicarakan.

3. Tahapan konfrontasi. Tahapan konfrontasi adalah tahapan penyajian persoalan yang harus dipecahkan sesuai dengan tingkat kemampuan dan pengalaman siswa.

4. Tahap inkuri. Adalah tahapan terpenting dalam model pembelajaran peningkatan kemampuan berpikir.

5. Tahap akomodasi. Adalah tahapan pembentukan pengetahuan baru melalui proses penyimpulan.

6. Tahap transfer. Adalah tahapan penyajian masalah baru yang sepadan dengan masalah yang disajikan.

\section{Model Pembelajaran Konvensional}

Dalam pembelajaran, guru banyak menggantungkan pada buku teks. Materi yang disampaikan sesuai dengan urutan isi buku teks. Siswa diharapkan memiliki pandangan yang sama dengan guru, atau sama dengan buku teks tersebut. Alternatif-alternatif perbedaan interpretasi diantara siswa terhadap fenomena sosial yang kompleks tidak dipertimbangkan.

Ketika menjawab pertanyaan siswa, guru tidak mencari kemungkinan cara pandang siswa
Jurnal Pendidikan Fisika

p-ISSN 2252-732X

e-ISSN 2301-7651

dalam menghadapi masalah, melainkan melihat vapakah siswa tidak memahami sesuatu yang dianggap benar oleh guru. Menurut Budiningsih (2005) karakteristik pembelajaran tradisional dibagi atas enam bagian, yaitu:

1. Kurikulum disajikan dari bagian-bagian menuju keseluruhan dengan menekankan pada keterampilan-keterampilan dasar.

2. Pembelajaran sangat taat pada kurikulum yang telah ditetapkan.

3. Kegiatan kurikuler lebih mengandalkan pada buku teks dan buku kerja.

4. Siswa-siswa dipandang sebagai kertas kosong yang dapat digoresi informasi oleh guru, dan guru-guru pada umumnya menggunakan cara didaktik dalam menyampaikan informasi kepada siswa.

5. Penilaian hasil belajar siswa atau pengetahuan siswa dipandang sebagai bagian dari pembelajaran, dan biasanya dilakukan pada akhir pelajaran dengan cara testing.

6. Siswa-siswa biasanya bekerja sendiri-sendiri, tanpa ada group proses dalam belajar.

\section{Metode Penelitian}

Penelitian ini akan dilaksanakan di SMA Negeri 1 Balige. Waktu penelitian dilakukan pada semester I TP 2008/2009. Populasi dalam penelitian ini adalah seluruh siswa kelas $\mathrm{X}$ SMA Negeri 1 Balige Tahun ajaran 2008/2009. Sampel penelitian didapat dua kelas, kemudian dipilih kelas kontrol dan kelas eksperimen dengan cara random sampling, yaitu dengan melakukan undian. Satu kelas sebagai kelas eksperimen (dengan model pembelajaran kemampuan berpikir) dan satu lagi sebagai kelas kontrol (dengan model pembelajaran konvensinal).

Rancangan penelitian ini dapat dilihat pada tabel di bawah ini.

Tabel 1. Rancangan eksperimen

\begin{tabular}{|l|c|c|c|}
\hline \multicolumn{1}{|c|}{ Sampel } & Pretes & Perlakuan & Postes \\
\hline K. eks & $\mathrm{T}_{1}$ & $\mathrm{X}_{1}$ & $\mathrm{~T}_{2}$ \\
\hline K. kontrol & $\mathrm{T}_{1}$ & $\mathrm{X}_{2}$ & $\mathrm{~T}_{2}$ \\
\hline
\end{tabular}


Hutagalung, A.M.: Pengaruh Model Pembelajaran Peningkatan Kemampuan Berpikir Terhadap Hasil Belajar Pada Materi Pokok Besaran dan Pengukuran di Kelas X SMA Negeri 1 Balige.

Keterangan: $\mathrm{T}_{1}=$ pretes; $\mathrm{T}_{2}=$ postes; $\mathrm{X}_{1}=$ model pembelajaran peningkatan kemampuan berpikir; $\mathrm{X}_{2}=$ model pembelajaran konvensional.

\section{Teknik Analisis Data}

Langkah-langkah dalam teknik analisis data adalah:

1. Pemeriksaan uji normalitas data digunakan uji Liliefors (Sudjana,2002).

2. Pemeriksaan uji homogenitas varians sampel. Uji homogenitas varians menggunakan uji $\mathrm{F}$ dengan rumus (Sudjana, 2002)

$$
F=\frac{s_{1}{ }^{2}}{s_{2}{ }^{2}}
$$

Keterangan: $s_{1}{ }^{2}=$ varians terbesar; $s_{2}{ }^{2}=$ varians terkecil.

Kriteria pengujian: terima sampel berasal dari populasi yang berdistribusi normal jika $F_{(1-\alpha)_{\left(n_{1}-1\right)}}\left\langle F\left\langle F_{1 / 2 \alpha\left(n_{1}-1, n_{2}-1\right)}\right.\right.$ Nilai $\alpha$ yang digunakan adalah $\alpha=0,10$.

3. Pengujian hipotesis

Bila data penelitian berdistribusi normal dan homogen maka menguji hipotesis menggunakan uji beda dengan rumus (Sudjana, 2002).

$$
t=\frac{\overline{x_{1}}-\bar{x}_{2}}{s \sqrt{\frac{1}{n_{1}}+\frac{1}{n_{2}}}}
$$

Dengan $\mathrm{t}=$ distribusi $\mathrm{t}$

$x_{1}=$ nilai rata-rata kelompok eksperimen

$\bar{x}_{2}=$ nilai rata-rata kelompok kontrol

$\mathrm{n}_{1}=$ ukuran kelompok eksperimen

$\mathrm{n}_{2}=$ ukuran kelompok kontrol

Kriteria pengujian adalah terima $\mathrm{H}_{0}$ jika $-t_{(1-1 / 2 \alpha)}\left\langle t\left\langle t_{(1-1 / 2 \alpha)}\right.\right.$, dimana $t_{(1-1 / 2 \alpha)}$ didapat dari daftar distribusi $\mathrm{t}$ dengan $\mathrm{dk}=\mathrm{n}_{1}+\mathrm{n}_{2}-2$, untuk harga-harga t lainnya $\mathrm{h}_{0}$ ditolak (Sudjana, 2002).

\section{Hasil Penelitian dan Pembahasan Deskripsi Hasil Penelitian}

Penelitian ini merupakan penelitian Quasi Eksperimen yang melibatkan dua kelas
Jurnal Pendidikan Fisika

p-ISSN 2252-732X

e-ISSN 2301-7651

yang diberi model pembelajaran yang berbeda yaitu kelas eksperimen yang diajar dengan Model Pembelajaran Peningkatan Kemampuan Berpikir dan kelas kontrol yang diajar dengan Model Pembelajaran Konvensional. Oleh karena itu, sebelum kedua kelas diterapkan perlakuan yang berbeda, maka kelas terlebih dahulu diberikan pretes yang bertujuan untuk mengetahui kemampuan awal belajar siswa pada masing-masing kelas.

Perolehan nilai rata-rata pretes kelas eksperimen sebesar 4,213 dan pada kelas kontrol 4,125. Setelah pada sampel diterapkan model pembelajaran yang berbeda dimana kelas eksperimen diterapkan model pembelajaran peningkatan kemampuan berpikir dan kelas kontrol diterapkan model pembelajaran konvensional diperoleh hasil postes kedua kelas diperoleh nilai rata-rata kelas eksperimen 6,975 dan kelas kontrol 5,93.

Uji persyaratan analisa data meliputi uji normalitas data pretes dan postes serta uji homogenitas data pretes. Pengujian normalitas data dilakukan dengan menggunakan uji Lilliefors, diperoleh bahwa nilai pretes dan postes kedua kelompok sample memiliki ata yang normal atau $L_{o}<L_{\text {tabel }}$ pada taraf signifikan 0,05 dan $\mathrm{N}=40$.

Tabel. 2. Ringkasan Perhitungan uji Normalitas Data Pretes dan Postes

\begin{tabular}{|l|l|l|l|l|l|}
\hline $\begin{array}{l}\mathrm{N} \\
\mathrm{o}\end{array}$ & Data & Kelas & $\mathrm{L}_{\text {hitung }}$ & $\mathrm{L}_{\text {tabel }}$ & $\begin{array}{l}\text { Kesim } \\
\text { pulan }\end{array}$ \\
\hline 1 & Pretes & Eks. & 0,1038 & & Normal \\
2 & Pretes & Kontrol & 0,0849 & 0,1401 & Normal \\
3 & Postes & Eks. & 0,1271 & & Normal \\
4 & Postes & Kontrol & 0,1391 & & Normal \\
\hline
\end{tabular}

Selanjutnya pengujian homogenitas dilakukan dengan menggunakan uji $\mathrm{F}$ untuk mengetahui apakah kelompok sampel berasal dari populasi yang homogen atau tidak. Dari hasil uji homogenitas diperoleh nilai $\mathrm{F}$ hitung $=1,0481$ (pada pretes) dan $F_{\text {hitung }}=1,070$ (pada postes) sedangkan $F_{\text {tabel }}=1,704$. Karena $F_{\text {hitung }}<F_{\text {tabel }}$ maka data pretes dan postes kedua sample homogen. 
Hutagalung, A.M.: Pengaruh Model Pembelajaran Peningkatan Kemampuan Berpikir Terhadap Hasil Belajar Pada Materi Pokok Besaran dan Pengukuran di Kelas X SMA Negeri 1 Balige.

Untuk pengujian hipotesis dilakukan dengan uji t yaitu membedakan rata-rata hasil belajar postes siswa kelas eksperimen dan kelas kontrol dengan tujuan untuk mengetahui ada tidaknya pengaruh model pembelajaran peningkatan kemampuan berpikir dan model pembelajaran konvensional terhadap hasil beajar siswa pada materi pokok Listrik Statis di kelas X Semester I SMA Negeri 1 Balige Tahun Pelajaran 2008/2009. Hasil pengujian hipotesis pada taraf signifikan 0,05 dan $\mathrm{dk}=78$, diperoleh $\mathrm{t}_{\text {hitung }}=5,303$ sedangkan $\mathrm{t}_{\text {tabel }}=1,994$. Karena $\mathrm{t}_{\text {hitung }}>\mathrm{t}_{\text {tabel }}$ berarti $\mathrm{H}_{a}$ diterima atau $\mathrm{H}_{o}$ ditolak, maka dapat disimpulkan ada pengaruh model pembelajaran peningkatan kemampuan berpikir terhadap hasil belajar siswa.

\section{Pembahasan}

Hasil pengujian hipotesis menunjukkan adanya pengaruh model pembelajaran peningkatan kemampuan berpikir pada pokok bahasan Listrik Statis. Setelah dilakukan perlakuan yang berbeda pada kedua sampel, diperoleh nilai rata-rata kelas eksperimen 6,975 sedangkan kelas kontrol adalah 5,925. Hasil ini memperlihatkan bahwa pengajaran dengan menerapkan model pembelajaran peningkatan kemampuan berpikir memberikan hasil belajar Fisika yang lebih baik dari pada dengan menerapkan model pembelajaran konvensional.

Berdasarkan hasil penelitian dan pengujian hipotesis dapat dilihat bahwa dengan menerapkan model pembelajaran peningkatan kemampuan berpikir terbukti dapat meningkatkan hasil belajar siswa yang lebih baik dibandingkan dengan hasil belajar siswa yang diajarkan dengan model pembelajaran konvensional. Dapat disimpulkan bahwa ada pengaruh model pembelajaran peningkatan kemampuam berpikir terhadap hasil belajar siswa pada materi pokok listrik statis di kelas X Semester I SMA Negeri 1 Balige Kab. Tobasa TP. 2008/2009.
Jurnal Pendidikan Fisika

p-ISSN 2252-732X

e-ISSN 2301-7651

\section{Simpulan}

Setelah dilakukan tabulasi, perhitungan dan pengujian hipotesis diperoleh beberapa kesimpulan, yaitu (1) Rata-rata pretes kelas eksperimen sebelum diberikan pembelajaran adalah 4,2125 dan setelah deberikan perlakuan dengan mengunakan model pembelajaran peningkatan kemampuan berpikir diperoleh hasil belajar siswa (postes) sebesar 6,975. Hal ini menunjukan bahwa peningkatan hasil belajar siswa setelah diberikan perlakuan. (2) Rata-rata pretes kelas kontrol sebelum diberikan perlakuan adalah sebesar 4,125 dan setelah diberikan perlakuan dengan mengunakan model konvensional diperoleh hasil belajar siswa (postes) sebesar 5,925. Hal ini menunjukkan bahwa adanya peningkatan hasil belajar siswa seteah diberikan perlakuan. Namun lebih kecil dibandingkan dengan model pembelajaran peningkatan kemampuan berpikir. (3) Ada pengaruh model pembelajaran peningkatan kemampuan berpikir terhadap hasil belajar siswa pada materi pokok Listrik Statis di kelas $\mathrm{X}$ semester I SMA Negeri 1 Balige Kab. Tobasa Tahun Pelajaran 2008/2009.

\section{Daftar Pustaka}

Atmadi. 2009. Transformasi Pendidikan (Memasuki Millenium Ketiga). Yogjakarta: Kanisius.

Budiningsih, C.A. 2005. Belajar dan Pembelajaran. Jakarta: Rineka Cipta.

Dimiyanti dan Mudjiono. 1999. Belajar dan Pembelajaran. Bandung: Rineka Cipta.

Sagala, S. 2003. Konsep dan Makna Pembelajaran. Bandung: Alfabeta.

Sanjaya, W. 2006. Pembelajaran Dalam Implementasi KBK. Jakarta: Kencana Prenada Media Group.

Sudjana. 2002. Metode Statistika. Bandung: Tarsito. 